\title{
The Lycian Name of Iranian Origin MiOrapata and Its Variants
}

\author{
Ignasi-Xavier ADIEGO*
}

In Mørkholm - Neumann 1978 (the clearly out-of-date but only reference corpus of Lycian coin legends available), the name of the dynast MiOrapata appears under the numbers M 138 and M 139 in either a full or an abbreviated form, with the following variants:

$$
\begin{aligned}
& \text { M 138a miӨrapata } \\
& \text { M 138b miӨrapati } \\
& \text { M 138c miOrapati / m } \\
& \text { M 139a miӨrapata } \\
& \text { M 139b miӨrapat } \\
& \text { M 139c mïrap } \\
& \text { M 139d miӨra } \\
& \text { M 139e mi } \theta \\
& \text { M } 139 f \mathrm{mi}
\end{aligned}
$$

M 138 types show the forehead or the scalp of a lion on the obverse and the portrait of the dynast on the reverse; in M 139 types, the obverse is a lion's scalp, but the reverse bears a triskeles. In all the coin types, the name of the dynast is inscribed on the reverse. The obverse is always anepigraphic, with the exception of M 138b, where a letter $m$ is written inside the face of the beast.

Müseler 2016 presents 28 coins attributed to MiOrapata (VII, 66 to VII, 92; VII, 94), plus three coins dated "in the time of the dynast MiӨrapata" (VII, 93, VII, 95, VII, 96)." Almost all the legends present in these coins are already referenced in Mørkholm - Neumann. Only two legends are new:

$$
\begin{aligned}
& \text { mi } \theta r \text { (VII, 77) } \\
& \text { mitrapata } w \text { (VII, 74) }
\end{aligned}
$$

The first one is simply another form of abbreviating the name mitrapata. The second example is more interesting. In this coin, $w$ must be the initial, probably of a place name: so Müseler proposes Phellos (Lycian Wehñte/i-) as a possible solution.

Basically, then, we have the legend miOrapata, with a variant miOrapati and different abbreviated forms of the name.

The form mi Orapati merits some attention. It appears in only a few coin types, but this existence is fully confirmed, as the following photo clearly shows:

\footnotetext{
* Prof. Dr. Ignasi-Xavier Adiego, Institut d'Estudis del Pròxim Orient Antic-Institute of Ancient Near Eastern Studies (IPOA) Universitat de Barcelona, Spain (ignasi.adiego@ub.edu; https://orcid.org/00000002-6223-5898).
} 


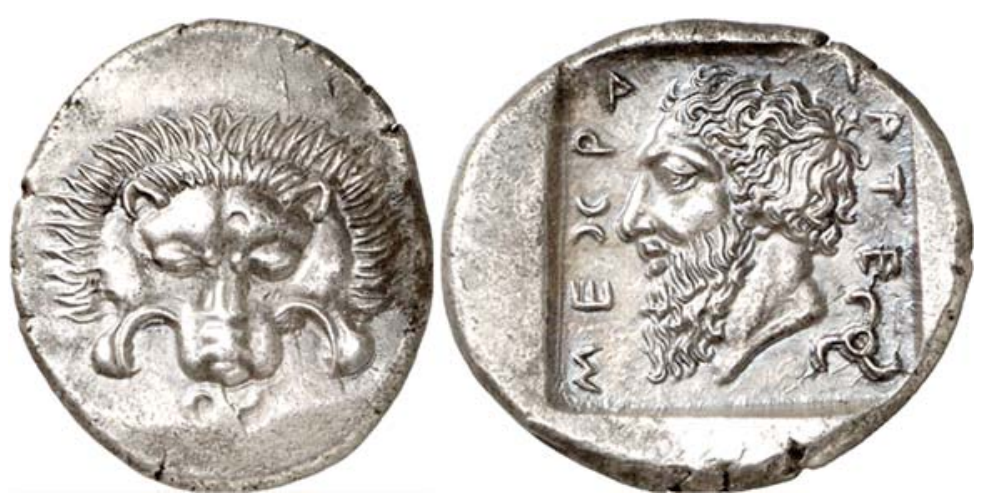

Fig. 1) LHS Numismatik AG, Auction 102, 29.04.2008

This variant is not analyzed either in Melchert 2004 or in Neumann - Tischler 2007. Melchert 2004 only notes “(form?)", whereas Neumann - Tischler 2007 mentions it as a "Variante”. Rüdiger Schmitt connected this variant in - $i$ to the parallel scenario of another Iranian name in Lycian, arttum̃para/artum̃para, which appears in a coin as arttumppari (M 231c). ${ }^{1}$ arttum̃pari has received slightly more attention from scholars: Meriggi 1980, 216 suggested that it might be a dative, though very tentatively, whereas Mørkholm - Neumann 1978, 27 proposed that this stem in $-i$ might be a "Lycianization" (Lykisierung) of the name, an idea repeated in Neumann - Tischler 2007, s. v. arttumpara and echoed in Schmitt 1982a, 378, Schmitt 1982b, IV/19, and Tavernier 2007,298 . As for the analysis as a dative, Schmitt 1982b, IV/19, fn. remarks that this interpretation does not fit a personal name in a coin legend. For this reason, he prefers to analyze it as a nominative, although he accompanies his proposal with a question mark.

Both explanations ("Lycianization" via adaptation as an $i$-stem vs. dative in - $i$ of an $a$-stem) encounter serious difficulties. It is not clear why a name in - $a$ would be "Lycianized" by becoming a $i$-stem, since personal names in $-a$ are very common in Lycian. Certainly, a large number of these Lycian names in $-a$ are or could be foreign names (aside from Arttumpara, MiOrapata, we can mention other Iranian names, like Erijamãna, Zissaprñna/Kizzaprñna, Erbbina, Humrxxa, or other ones of Greek origin, like Exeitija, Siderija, Pulenjda, while Zisqqa, Xpparama may be Carian), but many others seem to be pure Lycian names (Pertinamuwa, Purihimeiqa, Tuwala, Xinaxa, $X u d r e h i l a, H r i x \tilde{m} m a$, etc.); moreover, there is a productive $a$-declension for nouns in Lycian that includes male referents like xuga, or the agent nouns in $-z a^{2}$.

The explanation as a dative is, in principle, similarly unconvincing; as Schmitt rightly pointed out (cf. above), this case is not to be expected in a coin legend. However, there is a detail that may be of some relevance: both arttumpari and miOrapati appear in coins in which the legend accompanies a portrait of the dynast. Might the name expressed in the dative be reflecting a sort of dedication of the image? Or, even more intriguingly, might the illustration of the coins echo a real monument of the dynast in which the name appears in the dative ("to Arttum̃ara", "to MiOrapata")? This speculation could be extended to the very few cases in which the name of a Lycian dynast appears in the genitive: all the cases (but one) known to me of dynast names in the genitive on coins appear accompanying their portraits. The sole exception is M 231 = Babelon, II, 338, where arttumparahe is accompanied by the portrait of Heracles. If we assume in this latter case

\footnotetext{
${ }^{1}$ Schmitt 1982b, IV/23.

${ }^{2}$ On Lycian $a$-stems see now Martínez-Rodríguez 2018.
} 
that it could be an idealized representation of the dynast, all these examples could be interpreted as "(portrait) of X".

But even assuming this honorary character of these alleged datives arttumpari, miArapati, there exists another problem: in Lycian inscriptions, $-i$ is generally the ending for the dative singular of nouns (for instance ladi 'to the wife', of an $a$-stem lada-), but not for personal names: personal names systematically show an ending -aje, and in some exceptional cases, -a: Ijamaraje, Xatĩmaje, Eseimijaje, Padrĩma. However, there are indications that besides the common -aje a dative ending $-i$ also existed for personal names in - $a$ : In TL 21 we have a dative Ijeri of the same name that appears in N320 in the accusative as Ijeru. This accusative Ijeru comes very probably from ${ }^{\star}$ Ijera (with the sporadic but well-established change $\tilde{a}>u$ in Lycian), which presupposes an $a$ stem ${ }^{\star}$ Ijera. ${ }^{3}$ Therefore, lacking of a better interpretation, the analysis of these forms as datives cannot be totally ruled out.

A very recent publication of a coin hoard found in Musa Dağ (the Mount Musa), in the province of Antalya, not far from the settlement of Upper Olympus, offers some remarkable new types of

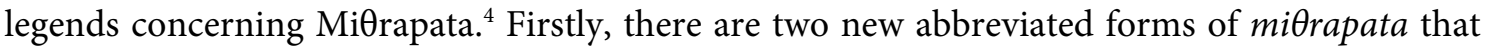
are not present in either Mørkholm - Neumann or Müseler:

$$
\begin{aligned}
& \text { miArapa (type III, 2g) }{ }^{5} \\
& \text { miOrapta (type IV. 1e) }
\end{aligned}
$$

However, the most interesting and appealing legends are the ones that present $I z$ instead of $x \theta$ :

mizrap (type I, 2)

mizra (type III, $2 \mathrm{~d}$ and $2 \mathrm{e}$ )

To these forms I can add two other legends with I, recently auctioned:

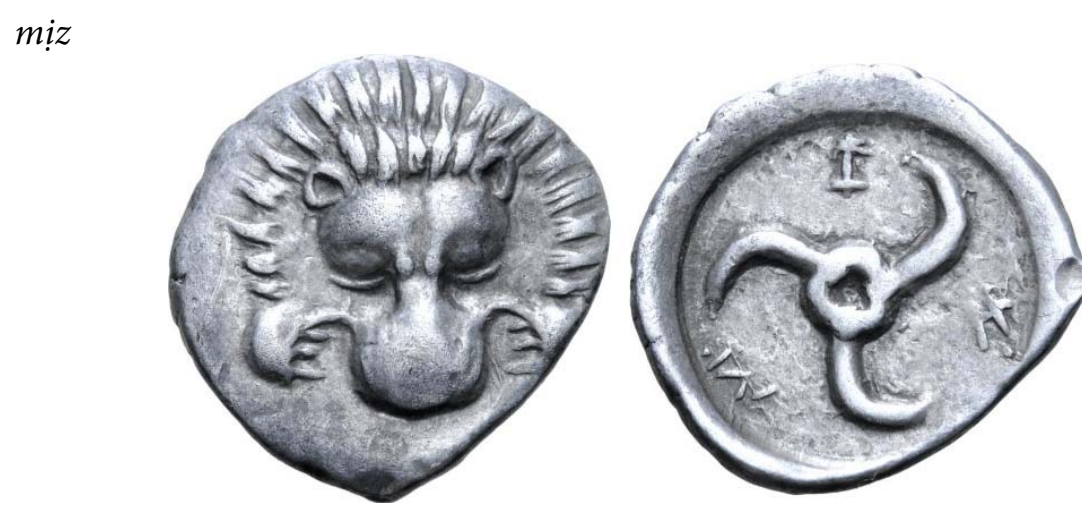

Fig. 2) Roma Numismatics Limited. E-Sale 67, Auction 405. 06.02.2020

mizpra or mizra $p$ ?

\footnotetext{
${ }^{3}$ Thus Melchert 2004, 96; cf. also Hajnal 1995, 117, n. 129.

${ }^{4}$ Büyükyörük - Çelik 2019.

${ }^{5}$ The types in Büyükyörük - Çelik 2019 correspond to a convenient classification of the coinages in function of the images represented on the reverse accompanying the triskeles: Type I = no symbol; Type II = spear; Type III = dolphin: Type IV = talus bone; Type V = ax.
} 


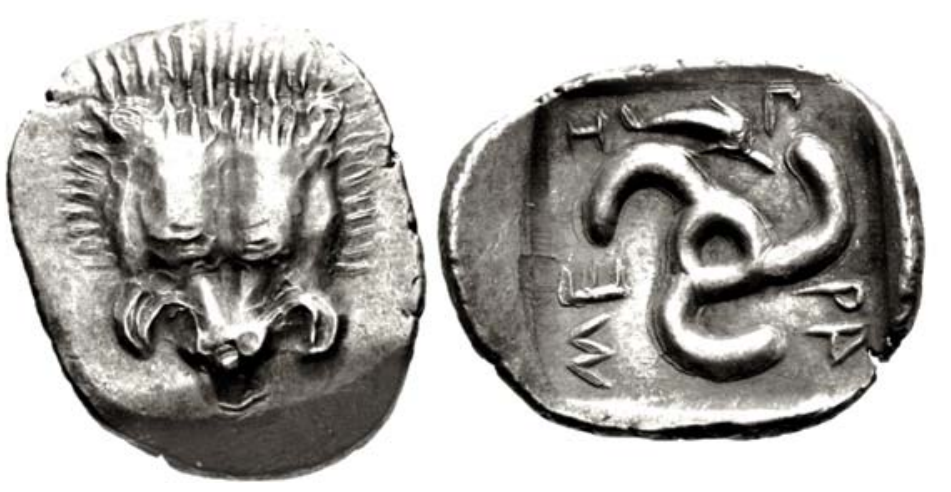

Fig. 3) Classical Numismatic Group, Electronic Auction 467, Lot 188, 06.05.2020

The first legend is unproblematic: the coin belongs to Type I (see note 2) and is a new abbreviation, corresponding to the $m i \theta$ legend present in other coins of the same type, but with $z$ instead of $\theta$.

The second one (in a coin of type III) is more enigmatic. The sequence of letters is $m-i-z-p-r-a$. I think that a phonological explanation, although theoretically possible, should be ruled out, as no parallel changes are known for Lycian. So, this is either a spelling mistake (an erroneous disposition of mizrap around the triskeles) or two different words: mizra presented vertically in boustrophedon, and $p$ as the initial of another word, probably a place name.

All these abbreviated forms (miz, mizra, mizrap, mizpra[sic? or mizra $p$ ) thus imply the existence of a spelling variant * mizrapata of the name mitrapata. An interesting consequence of this is that they invite us to reconsider the reading of two Lycian inscriptions, TL 64 (Isinda) and N 315 (Seyret). In both inscriptions, a dynast name read as mizrppata and generally equated with the dynast MiOrapata has been identified. ${ }^{6}$ However, the reading of the name mizrppata is far from sure in both tituli, and the new coin legend opens up the clear possibility of a reading as mizrapata. Let us look at these two attestations of an alleged mizrppata in greater depth.

TL 64 is actually a very fragmentary inscription - to my knowledge, not seen since the copy made by Heberdey, reproduced in Heberdey - Kalinka 1897, 31 and in Kalinka 1901:

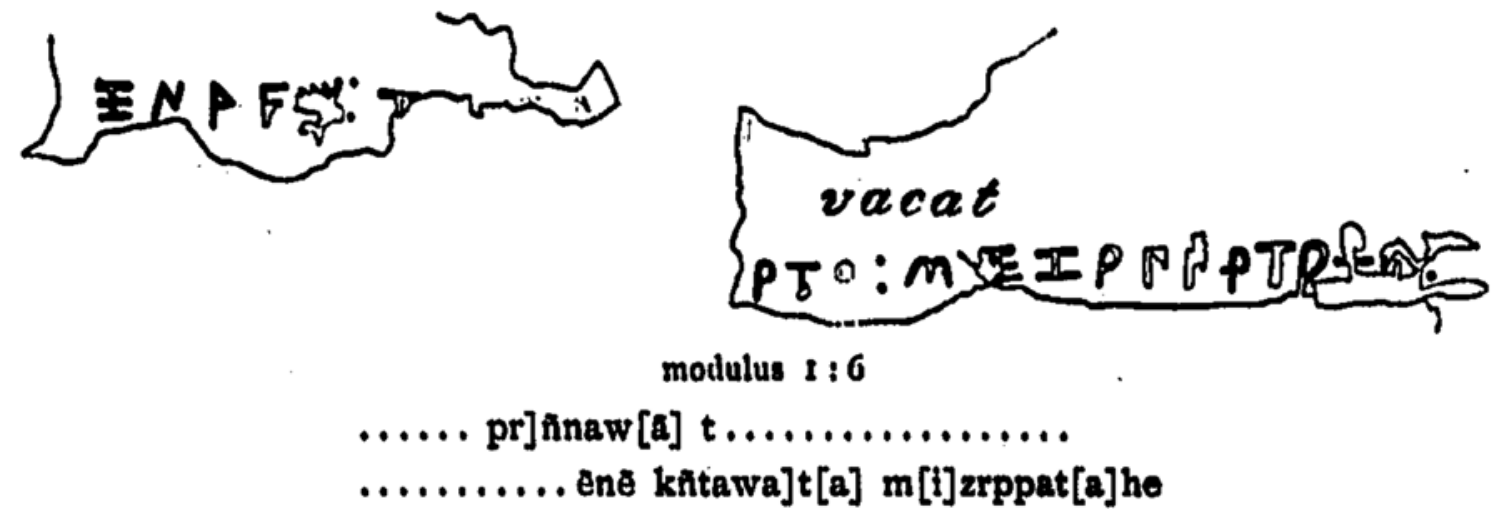

Fig. 4) TL 64 (Kalinka 1901)

The drawing clearly shows that the reading was not easy, and that the letters $\mathrm{P} a, \Gamma p, \mathrm{P} r$ were difficult to distinguish. Note, for instance, that the letter preceding $T t$ in the second line is identical to the letter $\mathrm{P} r$ after $\mathrm{I}$, but in the first case it is quite probably an $a$ (although Kalinka does

\footnotetext{
${ }^{6}$ For the possibility of two different dynasts, see Schürr 2012, 34 and the discussion below.
} 
not read it directly, the integration of [a] in the formula [ẽne xñtawa]t[a] is likely). In the controversial sequence read as mizrppat [a]he, the second $p$ appears damaged in the inscription, and the visible remains are also compatible with $\mathrm{P} a$.

Certainly, the presence of a spelling mizrppata in another Lycian inscription, $\mathrm{N} 315$, suggests the correctness of this reading. However, the inscription N 315 is also very damaged, and the reading mizrppata is in my opinion by no means guaranteed. Here is the drawing in Neumann 1979:

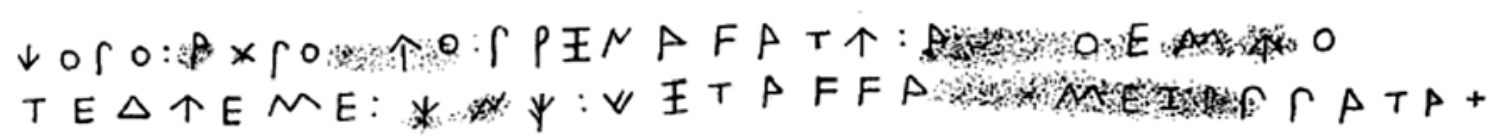

Fig. 5) N 315 (Neumann 1979)

Neumann reads mizrppatah, but the drawing shows a damaged area which also includes the first $p$. The photo of the squeeze in Neumann 1979 looks rather like a Jackson Pollock painting, so it is epigraphically useless. I have the suspicion that Neumann's reading may have been influenced by Kalinka's edition of TL 64. In this connection, it is interesting that Mørkholm - Neumann 1978, 18 mentions a form mizrapata from a still unpublished inscription, undoubtedly N 315, which appeared a year later in Neumann 1979. Schmitt 1982a, 382, fn. 59 recalled this first reading when commenting that ${ }^{\circ} \mathrm{rpp}^{\circ}$, instead of the expected ${ }^{\circ} \mathrm{rapa}{ }^{\circ}$, was not certain.

I am now quite convinced that Schmitt was right to express his doubts about ${ }^{\circ} r p p a^{\circ}$. The new coins of the dynast MiOrapata point clearly to a variant form mizrapata. They also seem to ratify that these variants in the coins allude to the same person - in all probability, the dynast Mizrapata quoted in TL 64 and N 315 is also our MiOrapata/Mizrapata. In my view, Schürr's hypothesis that these attestations in stone should be assigned to a later dynast of a slightly different name is unnecessary. ${ }^{7}$ The paleographic considerations that he adduces for defending a later date for TL 64 and N 315 seem very weak, due to the uncertainties about the copies published by Kalinka and Neumann respectively, and also about the use of paleographic variants as a clear-cut tool for dating in Lycian. To sum up, I think that the reading mizrppata in TL 64 and N 315 is far from sure, and that the new form mizrapata must be taken as a possible alternative reading in both inscriptions.

The question that remains open is the alternation of $\theta / z$. Leaving aside the form mizrppata, whose existence has been questioned in the preceding lines, we have two different sequences - $\theta r a-$ / - zra, a phenomenon that is not easy to explain. In principle, the Old Persian group - $\theta r$ (present in Median loanwords, since Proto-Iranian ${ }^{\star} \theta r$ regularly became $c ̧$ in Old Persian) represented phonetically $[\theta \mathrm{r}]$, which could be (and in fact was) adapted directly in Lycian by means of $\theta r(=[\theta \mathrm{r}])$.

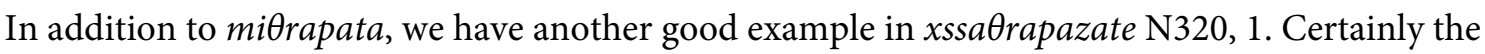
form xssadrapahi in the Stele of Xanthos (TL 44b, 36) points to a different articulation or perception of Iranian $[\theta \mathrm{r}]$ in its adaptation to Lycian, but it can be interpreted as representing [ðr] - that is, a spontaneous sonorization of $[\theta]$ in contact with $[r]$. The adaptation of $[\theta r]$ by means of Lycian $z r$, where $z$ represents /ts/ (so $[\theta \mathrm{r}] \rightarrow[\mathrm{tsr}]$ ) is less trivial. A possible explanation is that a group $[\theta \mathrm{rV}]$ was highly infrequent in (and perhaps alien to) Lycian phonology: aside from xssa $\theta$ rapazate

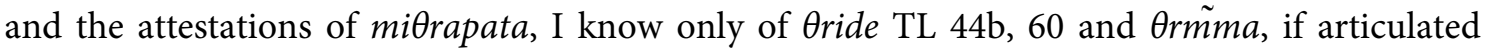
[ $\theta \mathrm{rm} . \mathrm{ma}$ ] (TL 44b, 44). Consequently, in borrowings it was probably replaced by [tsr], better attested in Lycian (xezrimeh TL 1; izraza TL 24; TL 26, 6, 20, 22; izredi TL 44a, 35, 41, 45; mizretije

\footnotetext{
${ }^{7}$ Schürr 2012, 34.
} 
TL 84, 1; mizratijehe TL 84, zru[ TL 148). In this context, the variant form xssadrapahi seems to be justified as another way of adjusting $[\theta r]$ to Lycian phonology ([ðr] is also very well attested in Lycian).

A different, and in my opinion more convincing hypothesis can be formulated by introducing chronological or dialectal dimensions. As is well known, Lycian $\theta$ is a sound that appeared in this Luwic dialect as a consequence of internal sound changes, not shared with its closest parent dialect, Milyan. For instance: /dVs/ $>/ \mathrm{dh} />/ \theta \theta /$ in ${ }^{\star}$ tedesi belonging to the father' (cf. Milyan tedesi TL 44d 67) >te $\theta \theta i,{ }^{*}$ ladasi 'belonging to the wife' > la $\theta \theta i$. We cannot rule out the possibility that the adaptation of Iranian $/ \theta$ / by means of Lycian $z, d$ might correspond either to a period prior to the appearance of $/ \theta /$ in Lycian or to an interference with a Luwic dialect (Milyan? - or a local variety of Lycian?) in which $/ \theta /$ did not exist.

In the first case, the fact that spellings with $z$ or $d$ coexist with spellings with $\theta$ could therefore be explained as an indication of different chronological layers for the emergence of these loanwords in Lycian. Forms with $z$ and $d$ entered Lycian before the changes that produced the sound $\theta$, and persisted over time. It is even possible that they became simple graphic archaisms.

In the second case, Lycian might have received these words through contact with non-standard varieties of Lycian, or with other Luwic dialects such as Milyan, mentioned above. Interestingly, MiOrapata/Mizrapata and xssaOrapa-/xssadrapa-are not the only examples of doublets of Iranian borrowings in Lycian. Another highly significant case is Kizzaprñna vs. Zissaprñna as the adaptation of Old Persian name Čiçafarnah -. Both forms appear in the Xanthos stele, not too distant from each other ${ }^{8}$, and in both cases refer to the same person. ${ }^{9}$

In conclusion, the new coin legends of the dynast MiӨrapata that have appeared in recent years show a spelling variant of the name Mizrapata. This form invites us to reconsider the reading mizrppata in two highly damaged Lycian inscriptions. Finally, the existence of doublets in Old Iranian loanwords in Lycian points to different spelling traditions linked to chronological or dialectal factors.

\section{Bibliography}

Büyükyörük - Çelik 2019 F. Büyükyörük - A. Çelik, Mithrapata ve Aruwãtijesi (Musa Dăğı?) Definesi, Cedrus VII, 2019, 239-265.

Hajnal 1995

I. Hajnal, Der lykische Vokalismus, Graz 1995.

Heberdey - Kalinka 1897

R. Heberdey - E. Kalinka, Bericht über zwei Reisen im südwestlichen Kleinasien, Denkschriften der kaiserlichen Akademie der Wissenschaften $45,1897,1-56$.

Kalinka 1901

E. Kalinka, Tituli Lyciae lingua Lycia conscripti (TAM I), Wien 1901.

Martínez-Rodríguez 2018

E. Martínez-Rodríguez, Revisiting gender and morphology in Lycian a-stem nouns, in: E. Rieken (ed.), 100 Jahre Entzifferung des Hethitischen, Wiesbaden 2018, 275-287.

\footnotetext{
${ }^{8}$ zisaprñna[--] TL 44c, 1 (also in coins: M 221 zisa[prñ]na ). kizzaprñna TL 44c, 11, 14; kizzaprñnã TL 44c. 15.

${ }^{9}$ Schmitt 1982b, IV/22.
} 
Melchert 2004

Meriggi 1980

Müseler 2016

Mørkholm - Neumann 1978

Neumann 1979

Neumann - Tischler 2007

Schmitt 1982a

Schmitt $1982 b$

Schürr 2012

Tavernier 2007
H. C. Melchert, A Dictionary of the Lycian Language, Ann Arbor 2004.

P. Meriggi, La declinazione dei nomi propri e dei pronomi in licio, Studi Micenei ed Egeo-Anatolici 22, 1980, 215-274.

W. Müseler, Lykische Münzen in europäischen Privatsammlungen, Istanbul 2016.

O. Mørkholm - G. Neumann, Die lykischen Münzlegenden, Göttingen 1978.

G. Neumann, Neufunde lykischer Inschriften seit 1901, Wien 1979.

G. Neumann, überarbeitet von J. Tischler, Glossar des Lykischen, Wiesbaden 2007.

R. Schmitt, Iranische Wörter und Namen im Lykischen, Serta Indogermanica: Festschrift für Günter Neumann zum 60. Geburtstag, Innsbruck 1982, 373-388.

R. Schmitt, Iranisches Personennamenbuch. V. Faszikel 4: Iranische Namen in den indogermanischen Sprachen Kleinasiens (Lykisch, Lydisch, Phrygisch), Wien 1982.

D. Schürr, Der lykische Dynast Arttumbara und seine Anhänger, Klio 94, 2012, 18-44.

J. Tavernier, Iranica in the Achaemenid period (ca. 550-330 B.C.), Leuven-Paris-Dudley 2007.

\section{Pers Kökenli Lykia İsmi MiӨrapata ve Değişik Yazım Şekilleri \\ Öz}

$\mathrm{Bu}$ makalede ismi mizrapata şeklinde yazılmış olan dinast MiOrapata'nın yeni sikke lejantları, özellikle varlığı artık sorgulanabilir olan diğer bir yazım formu mizrppata ile olası bağlantısı açısından incelenmektedir. Çift yazım şekli olan mizrapata/mïrapata ise döneme ya da lehçeye ait farklara bağlı yazım geleneklerinin bir sonucu olarak yorumlanabilir.

Anahtar sözcükler: Likçe epigrafisi, Likçe, Likçe sikkeler, Lykia hanedanları, Mithrapata, Likçedeki Pers isimleri.

\section{The Lycian name of Iranian Origin MiOrapata and Its Variants}

\section{Abstract}

In this paper, the new coin legends of the dynast MiOrapata with a spelling variant mizrapata are analyzed, particularly regarding its possible connection to another variant form, mizrppata, whose existence can now be questioned. As for the double spelling mizrapata/miArapata, it can be interpreted as the result of spelling traditions linked to chronological or dialectal factors.

Keywords: Lycian epigraphy, Lycian language, Lycian coins, Lycian Dynasts, Mithrapata, Iranian names in Lycian. 